\title{
Comprehensive model for predicting the fuel consumption in various harvesting methods of grass silage
}

\author{
Tapani Jokiniemi, Hannu Mikkola, Mikko Hakojärvi and Laura Alakukku \\ Department of Agricultural Sciences, University of Helsinki, Koetilantie 5, P.O. Box 28, FI-00014 University of Helsinki, Finland \\ e-mail: tapani.jokiniemi@helsinki.fi
}

\begin{abstract}
Fuel consumption of various forage harvesting methods was assessed with a theoretical calculation model, which was validated with field measurements. The examined harvesting methods were tractor-powered forage harvester (TPFH), self-propelled forage harvester (SPFH), self-loading forage wagon (SLFW), and combined baling and wrapping (CBW). The results from the field measurements indicated that the model was working either well or satisfactorily with the examined methods, apart from the CBW method, which would require re-defining the model coefficients. Model sensitivity analysis indicated that variables such as yield level, working width and transportation distance have a significant effect on the fuel consumption. When the working width was increased from $3 \mathrm{~m}$ to $9 \mathrm{~m}$, the fuel consumption of the examined methods decreased ca. $54-61 \%$. Increasing the working width by windrowing was found recommended for all examined methods. In all, the most energy efficient method was SLFW, but it was also most sensitive to transportation distance. With the transportation distance of $10 \mathrm{~km}$, the fuel consumption of the SLFW method was already 9-11\% higher compared to that of TPFH and SPFH methods. The strong effect of these variables may cause a wide variation in the fuel consumption of the examined methods, but the model can be used to standardize this effect. The results from this study can thus be used for approximate estimations of average fuel consumption of the examined forage harvesting methods.
\end{abstract}

Key words: fuel consumption, energy efficiency, forage harvesting, windrowing, forage transportation

\section{Introduction}

Energy consumption and energy efficiency have become essential topics in all industry sectors during the recent decades. European Union has set the "Energy Efficiency Directive" 2012/27/EU, which obligates the member states to reduce the primary energy consumption by $20 \%$ by the year 2020 , compared to projections made in 2007 (European Union 2012). Modern agriculture is strongly dependent on external energy inputs. According to analyses, the emissions from combustion of fossil fuels comprise about 7-10\% of total GHG emissions in commercial dairy farms (Chianese et al. 2009, Kristensen et al. 2011, Shortalla and Barnes 2013). In Finland, authorities have pursued to improve the energy efficiency of agriculture for example with voluntary energy programmes (Motiva 2015). In order to reduce the energy consumption and thus improve the sustainability of a production system, the energy consumption within the alternative subsystems must examined.

Major part of energy in grass silage production is consumed as indirect energy, in the production of nitrogen fertilizer. Fuels for harvesting machinery are, however, the principal direct energy input, constituting ca. $14 \%$ of all energy inputs. This corresponds to ca. $2.17 \mathrm{GJ}$ or ca. 50 litres diesel fuel per hectare (Mikkola and Ahokas 2009, Van linden and Herman 2014). In order to achieve the energy saving and climate objectives set by the authorities, and to improve the poor profitability of agriculture sector, it is essential to examine the fuel consumption of alternative forage harvesting methods.

The fuel consumption in forage harvesting has not been analysed comprehensively and there is lack of research material (Esala 2013). This study focused on evaluating the fuel consumption in the most common forage harvesting methods in Scandinavian humid climate conditions. Objectives of the study were:

1) developing a method which offers new, more precise method to evaluate the energy consumption in forage harvesting,

2) verifying the method with field measurements,

3) providing information for life cycle assessments of agriculture and food production, as well as for decision making for farmers,

4) helping to promote energy efficiency in agriculture and ultimately to reduce GHG missions and to improve the profitability of farming. 


\section{Materials and methods}

In Finland, most of the grass for silage is harvested as wilted silage, which refers to a method where the grass is left to dry at the field for ca. one day after cutting, depending on the weather conditions (Suokannas 2003). The target for the dry matter content of the wilted silage at harvest time is usually $30 \%$ or more (Srivastava et al. 2006). The grass can be collected directly from the windrows formed by the mower conditioner, or separate rake or windrower operation can be used to collect the grass into a one windrow from wider area (Culpin 1986, Srivastava et al. 2006). The most common methods for collecting the wilted silage are at the moment (in arbitrary order) (Esala 2013):

- self-loading forage wagon (SLFW),

- combined baling and wrapping to plastic film (CBW),

- tractor-powered forage harvester (TPFH), and

- self-propelled forage harvester (SPFH).

In the present study, the fuel consumption of silage harvesting was assessed by literature, theoretical calculations and measurements in practical harvesting conditions. Theoretical models for energy consumption of each method were built by using processing power equations provided by ASABE (ASABE 2011a, b), combined with basic motion and energy equations, to assess the energy requirement of propulsion of the machines or tractor-implement combinations. The effect of engine load on the engine efficiency and hence on the fuel consumption of the methods presented above was assessed by the aid of brake specific fuel consumption map provided by Jokiniemi et al. (2016). Field tests were conducted to verify the literature information and to validate the model results. The coefficients for ASABE equations were defined in North American conditions, which can be very different from those in Finland. Additionally, the variation range for the equations was very large, from $30 \%$ to $50 \%$ (ASABE 2011b) and model validation with field tests was thus required.

Energy requirement in forage harvesting was calculated as area specific $\left(\mathrm{l} \mathrm{ha}^{-1}\right)$ and mass specific $\left(\mathrm{l} \mathrm{t}^{-1}\right.$ in wet mass basis) fuel consumption. Area specific fuel consumption is useful for life cycle assessments since it enables relatively effortless calculation of energy consumption for certain field area. Mass specific fuel consumption is a better indicator for energy efficiency of production, and it is thus more suitable for optimising energy efficiency of forage production system. Analysis were conducted for a single harvest.

In the energy consumption analysis, the consumed fuel must be separated for field operations and transportation on road. When the area- or mass specific fuel consumption is defined for field operations, and mass- and distance specific fuel consumption (fuel consumption intensity) for transportation on road, the total fuel consumption can be calculated for each farm and each situation. Finally, to define the total direct energy consumption in each harvesting method, the energy used for filling the silage storage must be considered, except for the CBW method.

Structure of the study is illustrated in Figure 1. After the theoretical calculation model was built, the model sensitivity for each variable presented in the Figure 1 was examined:

- Field speed affects the engine load and thus the efficiency of the engine. The model sensitivity to the field speed, with respect to the fuel consumption, was examined with the speed range of 5 to $15 \mathrm{~km} \mathrm{~h}^{-1}$.

- Yield level affects the processing energy requirement per hectare but also the load of the harvesting machinery. The model sensitivity to the yield level, with respect to the fuel consumption, was examined with the yield range of 3 to $17 \mathrm{t} \mathrm{ha}^{-1}$ (at harvest moisture content).

- Working width has impact on the travelling distance on the field per unit of field area and it can thus have a notable effect on the energy requirement of propulsion of the machinery. The model sensitivity to the working width, with respect to the fuel consumption, was examined with the working width range of 2 to $17 \mathrm{~m}$.

- Transportation distance affects the energy requirement of transportations, but due to the differences in the transportation equipment, the effect may not be equal for all of the examined methods. The model sensitivity to the transportation distance, with respect to the fuel consumption, was examined with the distance range of 0 to $15 \mathrm{~km}$. 


\section{Modelled energy requirement Model validation}

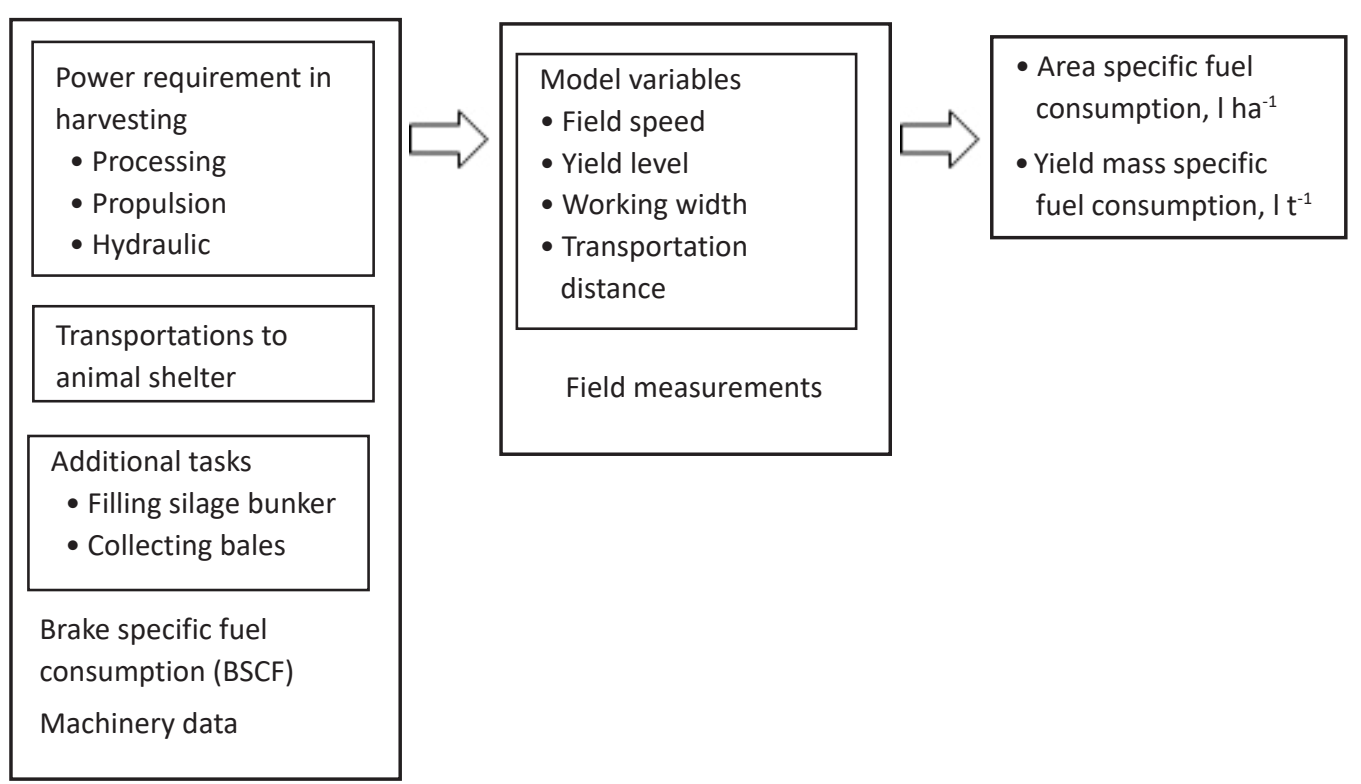

Fig. 1. Structure of the present study

\section{Theoretical assessments}

\section{Energy and power requirement}

The power requirement of a tractor or self-propelled harvesting machine consists of the processing power needed for the actual work and the propulsion power of the tractor-implement combination or a self-propelled machine. Processing power can be estimated with the Equation 1 (ASABE 2011a):

$P_{P}=a+b w+c q_{m}$

with $P_{p}=$ PTO power required by the implement $[\mathrm{kW}]$

with $a, b, c=$ machine specific coefficients $\left(\mathrm{kW}, \mathrm{kW} \mathrm{m}^{-1}, \mathrm{kWh} \mathrm{t}^{-1}\right.$ respectively)

with $w=$ implement working width $[\mathrm{m}]$

with $q_{m}=$ material mass flow rate, $\left[\mathrm{t} \mathrm{h}^{-1}\right]$ (w.b.)

The three parameters in Equation 1 represent: 1) the power requirement under no-load (idle) conditions, 2) power requirement with respect to the working width of the machine and 3) power requirement with respect to the material mass flow (feed rate). The machine specific coefficients with the ranges of variation are listed in the ASABE standard D497.7 (ASABE 2011b). Some of the values from the ASABE standard are suspiciously small compared to the others, for example the material mass flow coefficient for SLFW is only $0.3 \mathrm{kWh} \mathrm{t}^{-1}$, while the corresponding figure for round baler (fixed chamber) is $1.8 \mathrm{kWh} \mathrm{t}^{-1}$ and for forage harvester (both tractor-and self-propelled) $4.0 \mathrm{kWh} \mathrm{t}^{-1}$. The material mass flow coefficient for SLFW was therefore replaced by the value $1.5 \mathrm{kWh} \mathrm{t}^{-1}$, reported by Küper and Höner (2010).

It must be noticed that the type of forage was not considered in the ASABE standard D497.7. In the humid Finnish climate, the principal forage type is grass silage, while in the arid climate areas grass is often harvested as dry hay. The forage type may have a significant effect on the parameter 3 ), the power requirement with respect to the material mass flow, in the Equation 1.

The energy requirement for the propulsion of the machine or machine-implement combination on level ground is based on the rolling resistance force and mass: 
$E_{P}=\frac{F_{v} s}{\mu_{t}}=\frac{f m g s}{\mu_{t}}$

with $E_{p}=$ energy requirement of propulsion $[\mathrm{J}]$

with $F_{v}=$ rolling resistance $[\mathrm{N}]$

with $s=$ distance $[\mathrm{m}]$

with $\mu_{t}=$ transmission efficiency [-] (0.8 (Ahokas and Jokiniemi 2013)

with $f=$ rolling resistance coefficient $[-](0.06$, rough value for agricultural tires on firm ground (Renius 1999)

with $m$ = mass of the machine or machine combination $[\mathrm{kg}]$

with $g=$ gravitational acceleration $\left[9.81 \mathrm{~m} \mathrm{~s}^{-2}\right]$

The wheel slip should also be considered in the analysis, but since the draft power requirement in forage harvesting operations in small, this was neglected.

Many of the forage harvesting implements use hydraulic power. The power requirement of hydraulics $P_{h}(\mathrm{~kW})$ can be estimated with the hydraulic oil flow rate $q_{v}\left(\mathrm{~m}^{3} \mathrm{~s}^{-1}\right)$ and pressure $p(\mathrm{kPa})$ :

$P_{h}=q_{v} \Delta p$

with $P_{h}=$ power requirement of hydraulics $[\mathrm{kW}]$

with $q_{v}=$ hydraulic oil flow rate $\left[\mathrm{m}^{3} \mathrm{~s}^{-1}\right]$

with $p=$ hydraulic pressure $[\mathrm{kPa}]$

\section{Machinery data}

In order to analyse the theoretical energy consumption of forage harvesting, the following information is required: mass of the harvesting machinery, working width (cutting or windrowing width), field efficiency, yield, field speed, estimation of hydraulic pressure and flow rate and engine brake specific fuel consumption (engine efficiency).

Masses of the harvesting machinery are required in the Equation 2. Since forage wagons and balers carry a load of forage during the harvesting, the mass of the average load must be added to the mass of the machine. As the load is fluctuating from empty to full load, the average mass (=full load divided by two) can be used. The distance for the Equation 2 can be calculated from the processed area, working width and field efficiency. Material mass flow for the Equation 1 can be calculated from the working width, yield and field speed. To solve the energy requirement from the processing power in the Equation 1, also the duration of the work per area unit is required. This can be calculated from the distance per area unit and field speed.

To conduct a realistic analysis, machinery available in the market had to be chosen for the basis of the calculations. The machines with average capacity were chosen from the range of different manufacturers, assuming that the functional performance of different machine brands is equal. Technical data given by the manufacturers was used in the analysis (Tables 2-4).

For tractor powered implements, the tractors were chosen according to the power requirements of the implements (announced by the manufacturer). For tasks such as windrowing this was not possible, because the power requirement was so low that matching tractor was not available in the model ranges of conventional agricultural tractors. In these cases, the smallest model in the range was chosen. Tractor-wagon combinations to be pulled by the side of the forage harvesters were chosen in such manner, that the total mass of the loaded wagon was close to the maximum limit allowed by the Finnish road traffic regulations. The initial data and the machinery data for the analysis is presented in Tables $1-4$. It must be noted that the machinery data also contains estimations, since data was not always available. 
Table 1. Initial data for the analysis

\begin{tabular}{llll}
\hline Parameter & value & unit & Source \\
\hline Forage yield (single harvest, w.b.) ${ }^{1)}$ & 10 & $\mathrm{t} \mathrm{ha}^{-1}$ & Vallinhovi et al. 2014 \\
Dry matter content at harvest & 30 & $\%$ & Niskanen 1985 \\
Bulk density of wilted forage in wagon & 270 & $\mathrm{~kg} \mathrm{~m}^{-3}$ & Suokannas 2003 \\
Mass of a forage bale & 650 & $\mathrm{~kg}$ &
\end{tabular}

1) Estimation of average yield with a well managed operation, based on information by Vallinhovi et al. (2014)

Table 2. Machinery data for cutting and windrowing the grass

\begin{tabular}{lll}
\hline Variable & Cutting grass (Oy Elho Ab 2017) & Windrowing (Hankkija Oy 2017) \\
\hline Working width, $\mathrm{m}$ & 3.7 & 8.2 \\
Mass of the implement, kg & 3700 & 2050 \\
Power requirement, kW & 80 & 40 \\
Power of the tractor used, kW & 82 (AGCO Finland Oy 2017a) & 67.5 (AGCO Finland Oy 2017b) \\
Mass of the tractor used, kg & 4700 (AGCO Finland Oy 2017a) & 3750 (AGCO Finland Oy 2017b) \\
Field efficiency ${ }^{1)}$ & 0.8 & 0.8 \\
Field speed, $\mathrm{km} \mathrm{h}^{-1}{ }^{1)}$ & 11 & 10 \\
\hline${ }^{1)}$ Typical value according to ASABE standard D497 (ASABE 2011b)
\end{tabular}

Table 3. Technical data for forage harvesting machinery.

\begin{tabular}{|c|c|c|c|c|c|c|}
\hline Variable & \multicolumn{2}{|c|}{ TPFH (K-Maatalous 2015) } & $\begin{array}{l}\text { SPFH (Deere \& } \\
\text { Company 2017) }\end{array}$ & \multicolumn{2}{|c|}{$\begin{array}{l}\text { SLFW (B. Strautmann \& } \\
\text { Söhne GmbH u. Co. KG 2017) }\end{array}$} & $\begin{array}{l}\text { CBW (fixed chamber) } \\
\text { (NHK-keskus 2017) }\end{array}$ \\
\hline Mass of implement, kg & \multicolumn{2}{|l|}{2020} & 9755 & \multicolumn{2}{|l|}{9200} & 5950 \\
\hline Power requirement, kW & \multicolumn{2}{|l|}{103 (max) } & - & \multicolumn{2}{|l|}{103} & 97 \\
\hline Load volume, $\mathrm{m}^{3}$ & \multicolumn{2}{|l|}{-} & - & \multicolumn{2}{|l|}{32} & - \\
\hline Engine power, kW & \multicolumn{2}{|l|}{-} & 261 & \multicolumn{2}{|l|}{-} & - \\
\hline Hydraulic flow rate, I $\mathrm{min}^{-1}$ & \multicolumn{2}{|l|}{-} & - & \multicolumn{2}{|l|}{$40^{1)}$} & 40 \\
\hline Hydraulic pressure, $\mathrm{MPa}^{2)}$ & \multicolumn{2}{|l|}{-} & - & \multicolumn{2}{|l|}{12} & 7 \\
\hline Power of tractor used, kW & \multicolumn{2}{|c|}{$\begin{array}{l}99 \text { (AGCO Finland Oy } \\
2017 a)\end{array}$} & - & \multicolumn{2}{|c|}{112 (AGCO Finland Oy 2017a) } & $\begin{array}{l}99 \text { (AGCO Finland Oy } \\
\text { 2017a) }\end{array}$ \\
\hline Mass of used tractor, kg & \multicolumn{2}{|c|}{$\begin{array}{l}5200 \text { (AGCO Finland Oy } \\
\text { 2017a) }\end{array}$} & - & \multicolumn{2}{|c|}{5200 (AGCO Finland Oy 2017a) } & $\begin{array}{l}5200 \text { (AGCO Finland } \\
\text { Oy } 2017 a)\end{array}$ \\
\hline Field efficiency ${ }^{3)}$ & \multicolumn{2}{|l|}{0.7} & 0.7 & \multicolumn{2}{|l|}{0.7} & 0.7 \\
\hline Field speed, $\mathrm{km} \mathrm{h}^{-13)}$ & \multicolumn{2}{|l|}{5} & $10^{4)}$ & \multicolumn{2}{|l|}{5} & 8 \\
\hline \multicolumn{7}{|c|}{$\begin{array}{l}\text { 1) Value not declared by manufacturer, same value used as with baler; }{ }^{2)} \text { Esti } \\
\text { 2011b); }{ }^{4)} \text { Estimation for Scandinavian harvesting conditions }\end{array}$} \\
\hline \multicolumn{2}{|l|}{ Variable } & \multicolumn{3}{|c|}{$\begin{array}{l}\text { Forage wagon pulled by the side of forage } \\
\text { harvesters (Junkkari Oy 2017) }\end{array}$} & \multicolumn{2}{|c|}{ Bale wagon (Agri-Kymi Oy 2017) } \\
\hline \multicolumn{2}{|l|}{ Mass, kg } & \multicolumn{3}{|l|}{3500} & \multicolumn{2}{|l|}{2620} \\
\hline \multicolumn{2}{|l|}{ Volume/capacity, m³/pcs. } & \multicolumn{3}{|l|}{34} & \multicolumn{2}{|l|}{$18^{1)}$} \\
\hline \multicolumn{2}{|c|}{ Power of the tractor used, $\mathrm{kW}^{4)}$} & \multicolumn{3}{|l|}{82} & \multicolumn{2}{|l|}{82} \\
\hline \multicolumn{2}{|c|}{$\begin{array}{l}\text { Mass of used tractor, kg (AGCO Finland Oy } \\
\text { 2017) }\end{array}$} & 4700 & & & 4700 & \\
\hline Field speed, $\mathrm{km} \mathrm{h}^{-1}$ & & 5 or $10^{2)}$ & & & - & \\
\hline
\end{tabular}




\section{Brake specific fuel consumption}

When the energy requirement has been estimated, the fuel consumption of the tractor or self-propelled machine can be evaluated with a brake specific fuel consumption map. The brake specific fuel consumption map provides a tool to estimate the fuel consumption in varying load conditions. The fuel consumption $q$ (I) can be calculated from the energy required for work and propulsion $E$, brake specific fuel consumption BSFC and fuel density $\rho_{f}$.

$q=\frac{E \cdot B S F C}{\rho_{f}}$

with $q=$ fuel consumption $[I]$

with $E=$ energy required for work and propulsion [kWh]

with $B S F C=$ brake specific fuel consumption $\left[\mathrm{g} \mathrm{kWh}^{-1}\right]$

with $\rho_{f}=$ fuel density $\left[850 \mathrm{~g} \mathrm{I}^{-1}\right]$

Figure 2 presents a typical brake specific fuel consumption map of agricultural tractor engine (Jokiniemi et al. 2016). In this case the engine power was measured from the tractor PTO, and the brake specific fuel consumption includes thus the power losses due to the auxiliary systems of the tractor, as well as the power losses in the PTO drivetrain.

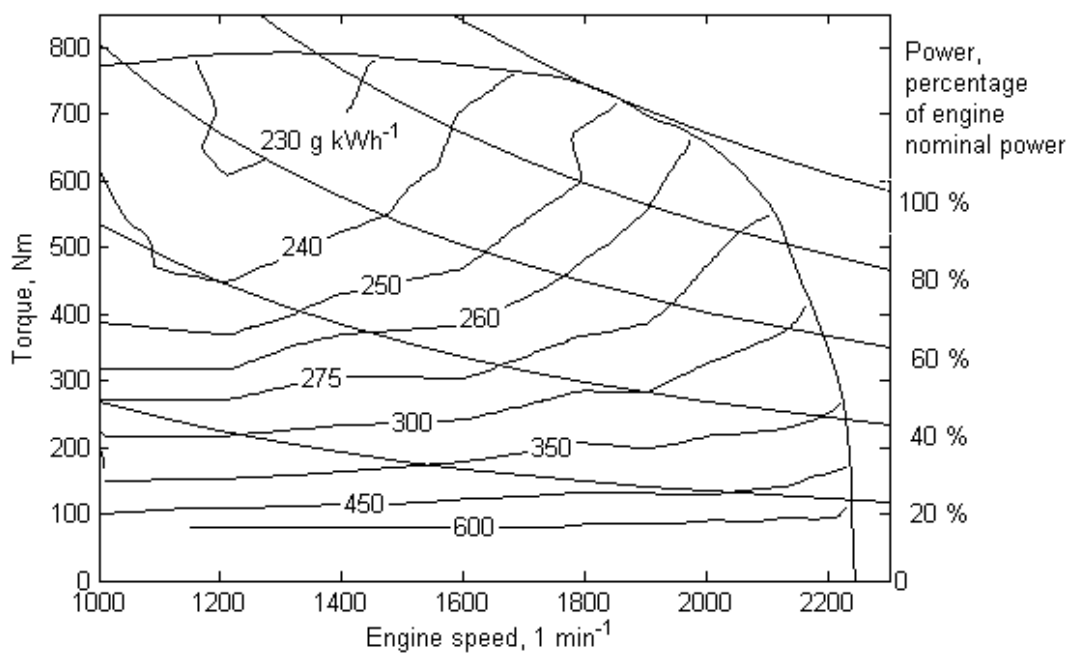

Fig. 2. Brake specific fuel consumption map of Valtra T163e Direct -tractor (Jokiniemi et al. 2016)

Although there is variation in the brake specific fuel consumption between individual tractor engines, the variation is low, and Figure 2 can thus be used for approximate estimations of agriculture tractor fuel consumption in general (Ahokas and Jokiniemi 2013). The percentage of engine nominal power was received by dividing the power requirement of work and propulsion with the nominal engine power. Then the used engine speed was estimated for the examined tasks, and the corresponding brake specific fuel consumption was solved from the specific fuel consumption map in Figure 2.

\section{Road transportations and additional tasks}

In agricultural transportations, the return trip is usually driven without load, and the energy used during return must also be considered. To evaluate the energy consumption in transportations, the method developed by Jokiniemi et al. (2016) was used:

$E_{i}=\frac{f g\left(2 m+m_{c}\right)+2 F_{L}}{m_{c} \mu_{e} \mu_{t}}$

with $E_{t}=$ energy consumption intensity $\left[\mathrm{MJ} \mathrm{t}^{-1} \mathrm{~km}^{-1}\right]$ 
with $f=$ coefficient of rolling resistance [-] $(0.03$, rough value for agricultural tires on hard surface [Renius 1999])

with $m=$ mass of the vehicle (tractor + wagon) $[\mathrm{kg}]$

with $m_{c}=$ mass of the payload $[\mathrm{kg}]$

with $F_{L}=$ aerodynamic drag $[N]$

with $\mu_{e}=$ engine efficiency $[-]$

with $\mu_{t}=$ transmission efficiency $[-]$

Equation (5) considers also the return trip with zero payload. The engine efficiency for Equation 5 was estimated with the aid of the brake specific fuel consumption map and the power required for motion of the machines (Eq. 2). When the density and the calorific value of the fuel are known, the engine efficiency can be calculated from the brake specific fuel consumption. The aerodynamic drag was calculated with the equation by Robert Bosch $\mathrm{GmbH}$ (2004):

$F_{L}=0.0386 \cdot \rho_{a} c_{d} A v^{2}$

with $\rho_{a}=$ density of air $\left[1.2 \mathrm{~kg} \mathrm{~m}^{3}\right]$

with $c_{d}=$ drag coefficient [-] (1, estimation for agricultural tractor based on information by Robert Bosch GmbH (2004)

with $A=$ cross-section area of vehicle $\left[4 \mathrm{~m}^{2}\right]$ (estimation for agricultural tractor)

with $v=$ velocity $\left[\mathrm{km} \mathrm{h}^{-1}\right]$

Finally, the energy consumption of filling the silage bunker, or collecting the bales from the field, had to be evaluated. Since no information about energy requirements in these tasks existed, only a very rough estimation was made. If the engine power of the tractor (or other machine) used for filling and compressing the silage bunker is $90 \mathrm{~kW}$, and the average engine load is estimated as $40 \%$ with engine speed of $17001 \mathrm{~min}^{-1}$, the brake specific fuel consumption is ca. $275 \mathrm{~g} \mathrm{kWh}^{-1}$, according to Figure 2. If the time used for processing the yield from one hectare is assumed to be the same as the time used for collecting the forage from the field with forage harvester, the fuel consumption of filling the silage bunker can be calculated as a product of the load percentage, engine power, brake specific fuel consumption and time. Similar approach can be used to calculate the fuel consumption for collecting the bales in the field.

\section{Field data measurements}

Fuel consumption measurements were conducted on two farms in summer 2016. Fuel consumption in SLFW and CBW methods was measured on the farm 1. Measurements in TPFH operation were accomplished on the farm 2. Information about fuel consumption and other performance parameters of the SPFH were received from a agricultural contractor, who was co-operating the project. Some parameters, for example working width, varied between the farms. The results were thus not directly comparable, but it was possible to compare the measured values with the results from the theoretical model since the model variables could be adjusted for each case individually.

Table 5. Information of the field measurements

\begin{tabular}{|c|c|c|c|c|c|c|c|}
\hline & Method & $\begin{array}{l}\text { Working } \\
\text { width, m }\end{array}$ & $\begin{array}{l}\text { Forage } \\
\text { type }\end{array}$ & Plants & $\begin{array}{l}\text { Examined area, } \\
\text { ha }\end{array}$ & $\begin{array}{l}\text { Number of } \\
\text { plots }\end{array}$ & $\begin{array}{l}\text { Size of plots, } \\
\text { ha }\end{array}$ \\
\hline Farm 1 & SLFW, CBW & $3.2 *$ & Grass & $\begin{array}{l}\text { Timothy (Phleum pratense), } \\
\text { meadow fescue (Festuca pratensis) }\end{array}$ & 57.7 & 9 & $4.1-11.1$ \\
\hline Farm 2 & TPFH & $9.5 * *$ & Grass & $\begin{array}{l}\text { Timothy (Phleum pratense), } \\
\text { meadow fescue (Festuca pratensis), } \\
\text { tall fescue (Festuca arundinacea) }\end{array}$ & 45.0 & 10 & $2.6-9.0$ \\
\hline
\end{tabular}

* Cutting width, no windrowing applied; ** Windrowing width 
For fuel consumption measurements on the farm 1, a Technoton DFM 100D dual chamber fuel flow meter (Technoton, Minsk, Belarus) was installed into a New Holland TM 150 tractor. The accuracy of the flow meter was $\pm 3 \%$, according to the information given by the manufacturer. The fuel flow meter generated one output voltage pulse for each $5 \mathrm{ml}$ of fuel consumed. The pulses from the flow meter were recorded with a HOBO UX120 Pulse Data Logger (Onset Computer Corporation, Bourne, Massachusetts, USA). The installation included a switch, which was used to define when the measurement was running, and whether the tractor was operating on field or on road. The tractor was also equipped with a GNS-recorder to associate the measured fuel consumption to individual field plots. Manual bookkeeping about field plots, working times and number of forage loads was made to support the data acquisition. With the SLFW method, the first two loads were weighed to estimate the mass of one forage load (in wet mass basis). Number of forage loads from each field plot was received from the bookkeeping. In the CBW method, the number of bales was received from the bookkeeping, and with the average mass of the bales, the forage yield (w.b.) could be calculated.

In the TPFH method on the farm 2, the fuel consumption information was captured and recorded from the tractor CAN bus with a Kvaser Memorator HS/HS CAN bus interface and datalogger (Kvaser Europe AB, Mölndal, Sweden). Previous studies indicate that the precision and accuracy of the fuel consumption data in the CAN bus is adequate for purposes such as life cycle assessments (Udompetaikul et al. 2011, Jokiniemi et al. 2016). The fuel consumption data was associated to field plots by the aid of manual bookkeeping. Fuel consumption was resolved from the can bus messages by decoding the recorded bus data traffic with a program written in MATLAB software (MathWorks, Natick, Massachusetts, USA), with the aid of SAE 1939 J standard CAN database. Mass of the yield was estimated by the volume of the forage wagons and the bulk density of forage at harvest dry matter content.

The fuel consumption of the SPFH was analysed from the information collected by the integrated documentation systems of the forage harvester. Data included: total operating hours, effective operating hours, processed area, travelling distance (on road and on field), fuel consumption (on road and on field) and mass of processed forage (wet basis). This information enabled the calculation of both area and yield mass specific fuel consumption. The data was collected during the total operation time of the machine (1272 hours), and it is thus very representative sample of silage harvesting with a SPFH. However, since only the total figures for the whole operating time were available, it was not possible to conduct any statistical analysis about the variation or make assessments about the effect of variables such as working (windrowing) width.

After the theoretical model was completed, it was applied to estimate the fuel consumption of the examined forage harvesting methods, and effect of field speed, yield level, working width, and transportation distance, on the fuel consumption. Finally, the measured fuel consumption results were used to validate the model and the results were compared to those found from literature.

\section{Results and discussion}

\section{Theoretical calculation model}

\section{Basic analysis}

Parameters such as working width, field speed and yield level have obviously effect on the fuel consumption of forage harvesting. In the basic analysis, the working (windrowing) width was set to $8.2 \mathrm{~m}$, which was the working width of the windrower chosen for Table 2. The yield was set to $10 \mathrm{t} \mathrm{ha}^{-1}$ (at harvest moisture content), which is a typical yield for single harvest pass of well managed grassland in Finland (Vallinhovi et al. 2014). The field speeds were chosen according to Table 3.

Figure 3 presents the results from the basic analysis, including the energy demand for the field operations alone: forage processing energy, propulsion of the machinery (including the energy required for pulling the wagons by the side of forage harvesters) and collecting the bales from the field in the CBW method. According to the results from the theoretical model in Figure 3, the TPFH and SPFH methods had the highest fuel consumption, with only minor difference compared to each other. SLFW and CBW methods consume less fuel than TPFH and SPFH methods, due to the less intensive processing of the material. From the examined methods, the SLFW uses most fuel for propulsion due to the high dead weight (Table 3), but when compared to TPFH and SPFH methods added with the pulling energy of the wagons, the fuel used at the field was still 34-38\% lower with the SLFW method. According to this analysis, the CBW method was the most energy efficient. The theoretical power requirement (coefficient $c$ in Equation 1) in baling is altogether suspiciously low, since the structure of the pickup and feeder system is very 


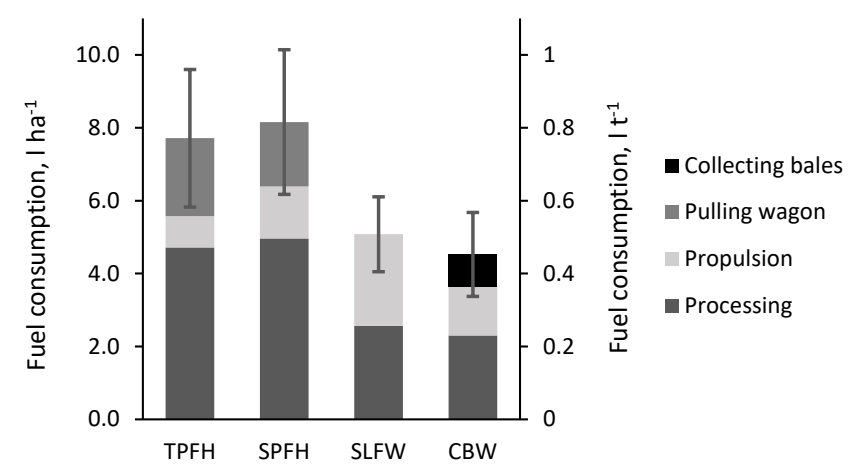

Fig. 3. Theoretical energy requirement of the field operations in the examined forage harvesting methods. The error bars express the variation due to the range of variation in coefficient factors $a, b$ and $c$ in Eq. (1) (ASABE 2011b).

similar compared to SLFW, but forming the bale should require notable amount of energy due to the friction forces of the rotating forage mass (Tremblay et al. 1997). According to Figure 3, a clear advantage of the CBW method, compared to the other methods, is the relatively low requirement of total propulsion energy (including energy required for pulling the wagons in forage harvester methods), due to the lower mass of the equipment. However, when collecting bales from the field is included, the total propulsion energy requirement is comparable to the other methods.

\section{Model sensitivity}

Field speed

Figure 4 presents the effect of field speed on the theoretical fuel consumption of the examined forage harvesting methods. In the basic analysis, the typical field speeds from Table 3 were used. In practice, the field speed must be adjusted according to adequate load of the harvesting machinery, depending on the yield, windrowing width and capacity of the machines. According to Figure 4, the field speed does not have particularly strong impact on the fuel consumption since the energy requirement for processing the forage and propulsion of the machinery remains constant. The field speed affects the fuel consumption mainly through the engine load and the brake specific fuel consumption of the engine, as Figure 2 indicates. Typical brake specific fuel consumption of agricultural tractor is $250 \mathrm{~g} \mathrm{kWh}^{-1}$ at nominal power (Ahokas and Jokiniemi 2013), and reduction from, for example, 300 $\mathrm{g} \mathrm{kWh}^{-1}$ to $250 \mathrm{~g} \mathrm{kWh}^{-1}$ means $17 \%$ reduction in fuel consumption. The effect of field speed on the energy consumption was quite similar with all the examined methods.

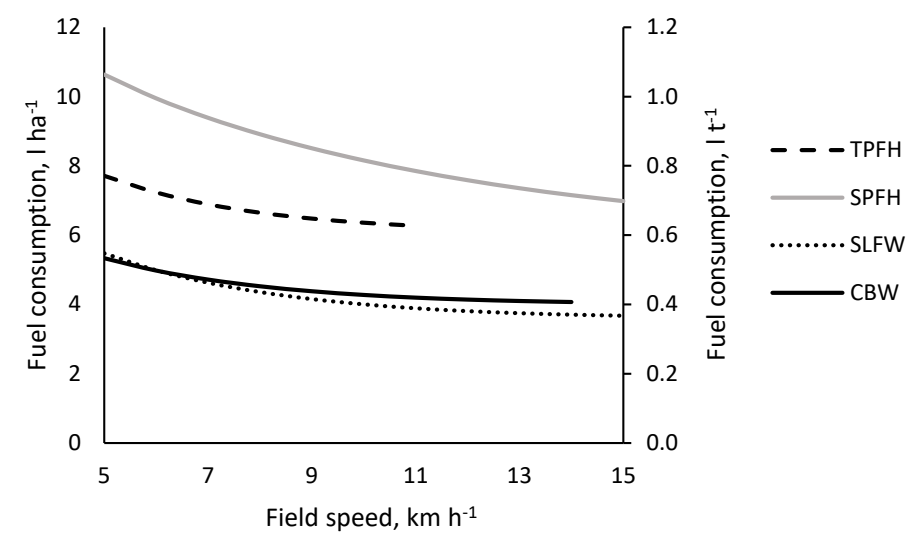

Fig. 4. Effect of the field speed on the theoretical energy consumption of the examined forage harvesting methods, with yield of $10 \mathrm{t} \mathrm{ha}^{-1}$ (w.b.) and working width of $8.2 \mathrm{~m}$. TPFH and SPFH methods include the energy required for pulling the forage wagon by the side of the harvester and CBW method includes the energy required to collect the bales from the field.

Yield level

The effect of the yield level on the fuel consumption of the examined forage harvesting methods is presented in Figure 5. The increase in the yield increases the area specific fuel consumption as the processing energy requirement increases. However, the theoretical yield mass specific fuel consumption decreases significantly when the yield level increases. When the yield increases e.g. from 5 to $10 \mathrm{t} \mathrm{ha}^{-1}$, the mass specific fuel consumption 
reduces ca. $38-44 \%$ with the examined methods. This is caused by two reasons. Firstly, while the yield level increases, the propulsion energy requirement per yield mass unit decreases, since shorter distance is required to harvest one mass unit of forage. This reduces the propulsion energy requirement. Secondly, the engine load of the harvesting machinery increases, and the engine works at a more economic fuel consumption area (Fig. 2). The field speed was assumed to remain constant in the Figure 5, which would not obviously be the case in practice, but the speed would be adjusted according to the engine load.
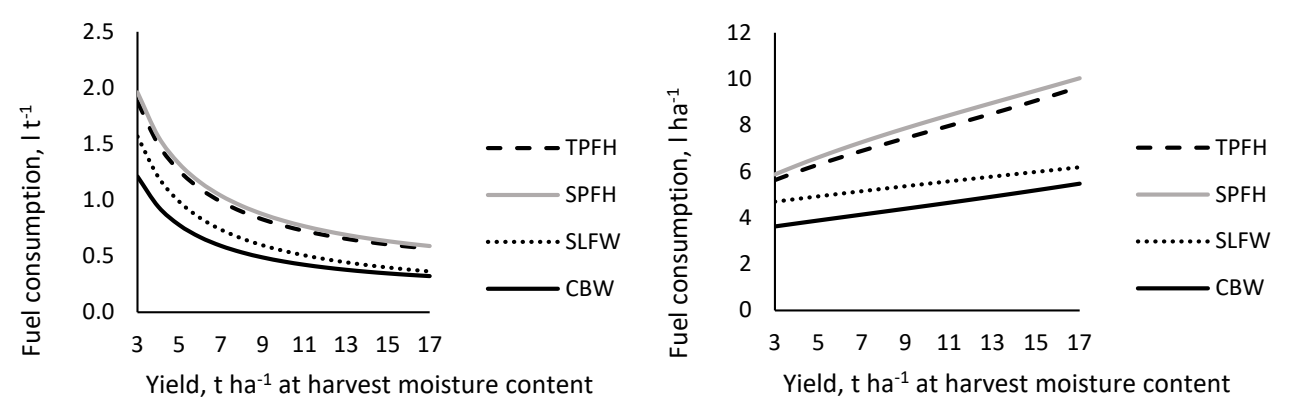

Fig. 5. Effect of yield on the theoretical energy consumption of the examined forage harvesting methods. Field speeds of the Table 3 were used and working width was $8.2 \mathrm{~m}$. TPFH and SPFH methods include the energy required for pulling the forage wagon at the side of the harvester and CBW method includes the energy required to collect the bales from the field.

\section{Working width}

Working width, which usually refers to windrowing width in this context, has a crucial effect on the fuel consumption in forage harvesting. An increase in working width decreases the distance required to harvest one area or mass unit of forage. While the total mass of the machines is high, the propulsion energy requirement decreases significantly when the travelled distance per area unit decreases. Furthermore, the engine load of harvesting machinery increases with the working width, which leads to lower brake specific fuel. This effect can be compensated by increasing the field speed, but only to some extent.

In the analysis presented above, the working width was assumed to be $8.2 \mathrm{~m}$. Figure 6 presents the theoretical effect of working width on the fuel consumption of the examined forage harvesting methods. Figure 6 indicates that increasing the working width reduces fuel consumption in forage harvesting very strongly with all the examined harvesting methods at first, but when the working width is further increased, the influence decreases. When the working width is increased from $3 \mathrm{~m}$ to $9 \mathrm{~m}$, the fuel consumption with the examined methods decreases ca. $54-61 \%$. The effect of further increase in the working width was modest. According to Figure 6, windrowing saves clearly more energy in the preceding operations than it consumes.

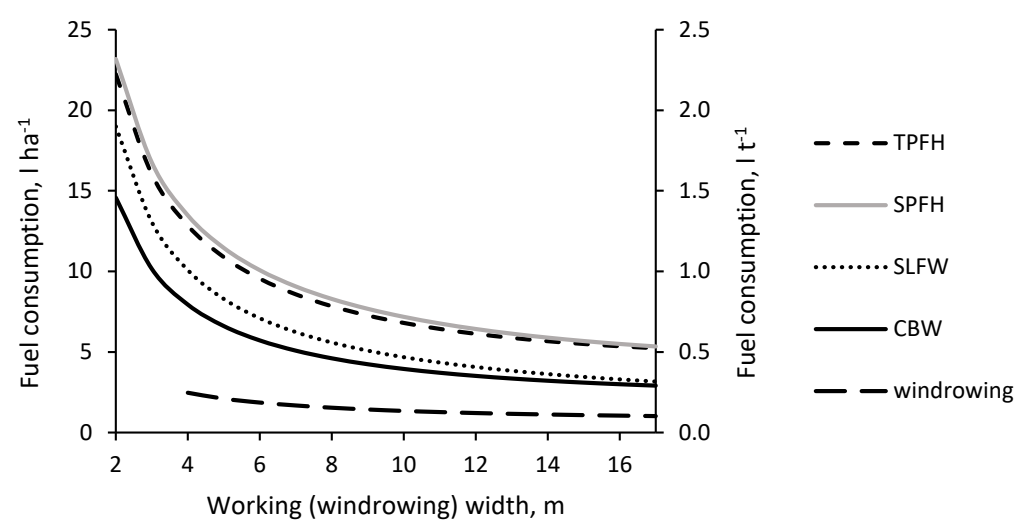

Fig. 6. Effect of windrowing width on the theoretical energy consumption in the examined forage harvesting methods. Field speeds date from Table 3 and the yield was $10 \mathrm{t} \mathrm{ha}^{-1}(\mathrm{wb})$. TPFH and SPFH methods include the energy required for pulling the forage wagon by the side of the harvester and CBW method includes the energy required for collecting the bales from the field. 


\section{Transportation distance}

Fuel consumption in transportation of the forage from the field to the storage facility, which is usually located close to the animal shelter, is obviously mainly dependent on the distance, but there are also differences between the harvesting methods. Theoretical transportation fuel consumption intensities, according to Equations 5 and 6 , were $0.10 \mathrm{I} \mathrm{km}^{-1}, 0.16 \mathrm{I} \mathrm{tkm} \mathrm{km}^{-1}$ and $0.08 \mathrm{I} \mathrm{tkm}^{-1}$ for TPFH \& SPFH, SLFW and CBW methods, respectively. These figures were calculated by using average speed of $30 \mathrm{~km} \mathrm{~h}^{-1}$. Return trip without cargo was included.

Figure 7 presents the effect of distance on the area- and yield mass specific fuel consumption in forage transportations. As fuel consumption intensities mentioned above indicated, the fuel consumption in transportation of forage with the SLFW method is ca. twice as large as that with the CBW method. This is caused by the high dead weight of the SLFW, which leads to relatively low payload compared to other methods. The payload-to-dead weight ratio (including only the mass of wagons) of SLFW was 0.9, compared to 2.6 and 4.5 for TPFH \& SPFH and CBW methods, respectively. When the fuel consumption of the transportation task, including the return trip without cargo, is allocated to the payload, the small payload and high dead weight lead to high fuel consumption intensity. The small difference between the TPFH \& SPFH and CBW methods is caused by slightly different masses of the transportation equipment used in the analysis.

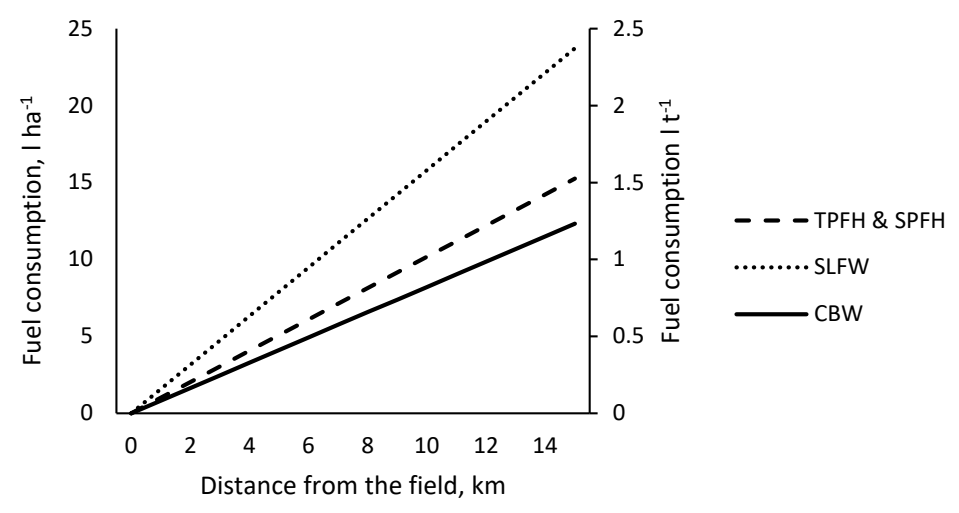

Fig. 7. Area- and yield mass specific fuel consumption in forage transportation with the examined forage harvesting methods. Fuel consumption intensities were 0.10 $\mathrm{Itkm}^{-1}$ for TPFH and SPFH, $0.16 \mathrm{I} \mathrm{tkm} \mathrm{km}^{-1}$ for SLFW and $0.08 \mathrm{I} \mathrm{km}^{-1}$ for CBW. Yield was $10 \mathrm{t} \mathrm{ha}^{-1}$ (w.b.) and the equipment specifications were taken from Tables 3 and 4.

\section{Total fuel consumption}

Figure 8 presents the total theoretical fuel consumption of the examined forage harvesting methods, also including the energy consumption of filling and compressing the silage bunker (except in the CBW method). The effect of the transportation distance is also considered. In 2002, the average distance from the field plots to the farmstead was $1.5 \mathrm{~km}$ on Finnish dairy farms (Myyrä 2002). This distance is probably considerably longer at the present.

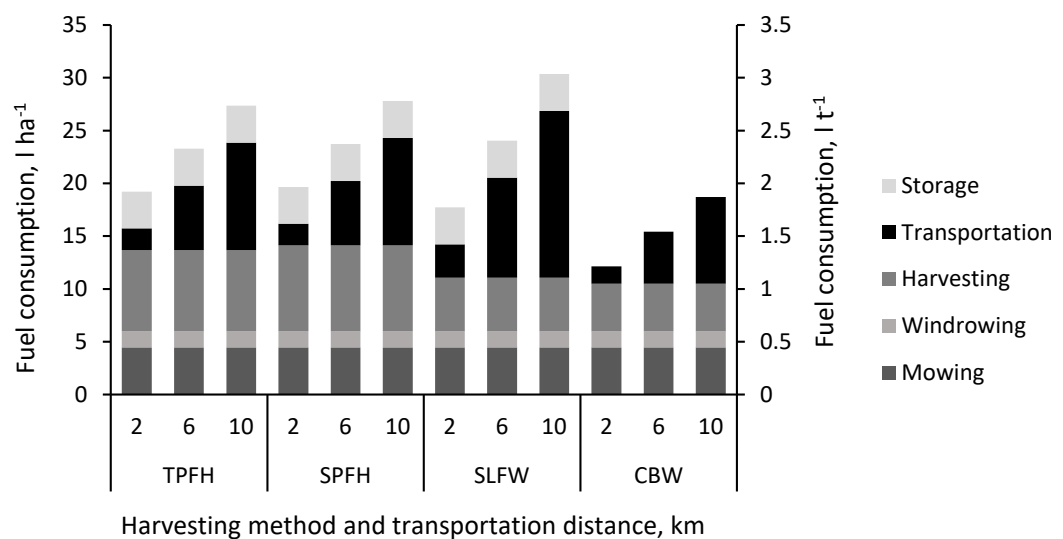

Fig. 8. Total theoretical fuel consumption in the examined forage harvesting methods. Yield was assumed to be $10 \mathrm{t} \mathrm{ha}^{-1}$ (w.b.) and the working width was $8.2 \mathrm{~m}$. Harvesting includes all the operations conducted at the field, e.g. pulling the forage wagon by the side of harvesters and collecting the bales. 
According to the model, the most energy efficient harvesting method was the CBW method. The difference between the other methods was small. Total fuel consumption in the SLFW method was 8-10\% lower compared to the TPFH and SPFH methods with the transportation distance of $2 \mathrm{~km}$, but the SLFW method is clearly more sensitive to an increase in transportation distance than the other methods. With the transportation distance of 6 $\mathrm{km}$, the fuel consumption of the SLFW method was already highest of the examined methods, and with the transportation distance of $10 \mathrm{~km}$, the fuel consumption of the SLFW method was 9-11\% higher compared to that of TPFH and SPFH methods.

\section{Measured fuel consumption and model validation}

Summary of the measured fuel consumption figures in the examined forage harvesting methods is presented in Table 6, including information about working width and yield level. Data from the SPFH method contained only the average values from the total operation time of the machine, and it was somewhat defective. It can therefore be used only for an approximate estimation. However, according to the theoretical analysis, the fuel consumption of the TPFH and SPFH methods was very similar (Fig. 8), and the assessments can be made based on the TPFH method.

Table 6. Summary of the fuel consumption measurements and comparison to the model results. Figures include only the harvesting work (work for pulling wagons in TPFH and SPFH -methods and collecting bales not included).

\begin{tabular}{|c|c|c|c|c|c|c|c|c|}
\hline Method & TPFH & & SPFH & & SLFW & & CBW & \\
\hline Yield, t ha ${ }^{-1}$ (w.b.) ${ }^{1)}$ & 17.4 & & 8.18 & & 12.0 & & 13.6 & \\
\hline$n^{3)}$ & 10 & & - & & 6 & & 7 & \\
\hline Fuel consumption & I ha ${ }^{-1}$ & $\mid t^{-1}$ & I ha-1 & $\mid t^{-1}$ & I ha-1 & $\mid t^{-1}$ & I ha $a^{-1}$ & $\mathrm{t}^{-1}$ \\
\hline Standard deviation & 1.59 & 0.08 & - & - & 0.75 & 0.04 & 1.16 & 0.15 \\
\hline Model prediction & 7.35 & 0.42 & 7.95 & 0.97 & 10.57 & 0.88 & 7.09 & 0.59 \\
\hline Deviation from measured, \% & -4.5 & -5.2 & -20 & -20 & 10 & 11 & -44 & -36 \\
\hline
\end{tabular}

${ }^{1)}$ Mean of all the field plots; ${ }^{2)}$ Estimation, no actual information available; ${ }^{3)} \mathrm{n}=$ number of field plots

Direct comparison of the measured fuel consumptions cannot be done due to the differences in working width and yields in the examined farms, apart from the CBW and SLFW methods, which were both examined at the farm 1. Cutting width at the farm 1 was 3.2 meter and no windrowing was applied. Unlike the theoretical model predicted, the measured fuel consumption in the CBW method was 15\% higher than in SLFW method. Furthermore, the fuel consumption in the CBW method was more than twice higher than that predicted by the model. On the farm 2, where the TPFH method was examined, the windrowing width was $9.5 \mathrm{~m}$ and the average yield was by far highest of the examined farms. According to the sensitivity analysis, an increase in working width or in yield level reduces the fuel consumption significantly, especially when the mass specific fuel consumption is considered. This may be the reason why the measured fuel consumption of the TPFH method on the farm 2 was the lowest of all the examined methods.

The average yield in this study varied between 8.18-17.4 $\mathrm{t} \mathrm{ha}{ }^{-1}$ and working width varied from 3.2 to $9 \mathrm{~m}$. To make the results comparable, the measured fuel consumption values must be examined with respect to the yield and applied working width. Figure 9 presents the dispersion of the measured fuel consumption, with respect to the yield. The modelled fuel consumptions in Table 6 and Figure 9 are calculated based on actual information (yield level and working width) from the examined farms. The results indicate that the model was working well for the TPFH method, and satisfactorily for the SLFW method. With the SPFH method, the results were based on the estimation of average working width, and they can thus be used only as approximate information. More detailed data collection, including the working width, would be required for more accurate analysis. By far the largest deviation between the measured and modelled fuel consumptions was found in CBW method, where the modelled fuel consumption figures were ca. $40 \%$ lower than the measured ones. This indicates that the ASABE coefficients for baling in Equation 1 are considerably too small and they need to be re-defined for grass silage baling in Finnish conditions and with European equipment. 


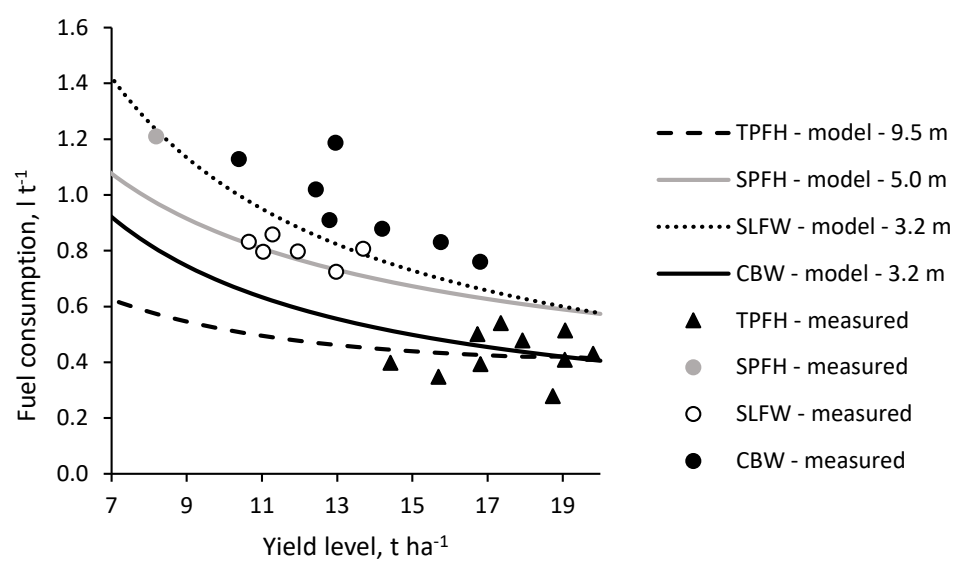

Fig. 9. Variation of the measured fuel consumptions, with respect to the yield, and the modelled consumption for each method. The working width used in the model was the same as the working width in the measurements with each method (estimation used with SPFH).

Fuel consumption in transportation was measured only with the SLFW method. Table 7 presents the results of the measurements, together with the model predictions. Table 7 indicates high fit with the modelled and measured fuel consumption intensities, considering the uncertainty caused by large number of indefinite variables. Since the calculation model for energy consumption in transportations was already validated in the original publication (Jokiniemi et al. 2016), it can be assumed that the results were valid also for TPFH \& SPFH and CBW methods. Principally the same calculation method was applied also to the propulsion energy requirement of the tractor-wagon combinations in the field operations of the TPFH and SPFH methods.

Table 7. Measured mean fuel consumption intensity in transportations and modelled fuel consumption intensities. Standard deviation for the measured values was 0.021 .

\begin{tabular}{llll}
\hline Method & TPFH \& SPFH & SLFW & CBW \\
\hline Fuel consumption intensity, I tkm ${ }^{-1}$, measured & - & 0.145 & - \\
Fuel consumption intensity, I tkm ${ }^{-1}$, model & 0.102 & 0.158 & 0.082 \\
Deviation from measured, \% & - & -9.0 & - \\
\hline
\end{tabular}

As a summary, the model seems to work satisfactorily with the examined harvesting systems, except the CBW method, which would require scaling up the coefficients for Equation 1. These need to be re-defined as a further development of the model. The advantage of the model is, that it enables a more precise case-by-case evaluation of the energy consumption in the forage harvesting operations, compared to the sole literature information. This is achieved by standardising some of the variables, which have a strong effect on the energy consumption, such as working width and yield level. Disadvantages of the model are, that it requires detailed information about the machinery, yields and infrastructure of the farm, and the effect of engine load with respect to changes in the field speed according to the yield cannot be fully compensated. However, in life cycle analysis, the national typicaland average values and figures can provide a satisfying result. When used as an aid in the choice of method, the detailed information should be available anyway.

\section{Comparison to literature}

Table 8 presents literature data for the fuel consumption in various forage harvesting operations. The figures in the literature are not always comparable since they are based on different definitions. For example, the figures reported by Arvidsson and Lingvall (2005), Frost and Binnie (2005), KTBL fuel consumption calculator (KTBL 2017) and Brownell et al. (2012) include the transportation of the forage to the storage facility. To make clear and unambiguous analysis, it would be necessary to separate the field operations and transportations clearly from each other. Table 8 also reveals that the fuel consumption of forage harvesting operations varies widely in the literature. This is obvious since there are several variables, such as the yield level, properties of the grass, conditions, features of the machinery, working width etc., which have a significant influence on the fuel consumption. 
Table 8. Modelled fuel consumption compared with the figures from literature.

\begin{tabular}{|c|c|c|c|c|c|}
\hline \multirow[t]{2}{*}{ Machine/task } & \multicolumn{2}{|c|}{$\begin{array}{l}\text { Modelled fuel } \\
\text { consumption ** }\end{array}$} & \multicolumn{2}{|c|}{ Literature information } & \multirow[t]{2}{*}{ Sources } \\
\hline & I ha ${ }^{-1}$ & $\mathrm{It}^{-1}$ & I ha ${ }^{-1}$ & $\mid t^{-1}$ & \\
\hline Mower-conditioner & 4.5 & 0.45 & $2.9-8.0$ & 0.5 & $\begin{array}{l}\text { Dalgaar et al. 2001, Rinaldi et al. 2005, Grisso } \\
\text { et al. 2010, Arshad and Shah 2016, KTBL 2017* }\end{array}$ \\
\hline Windrowing & 1.49 & 0.15 & $1.8-4.3$ & - & $\begin{array}{l}\text { Arvidsson and Lingvall 2005, Rinaldi et al. 2005, } \\
\text { Grisso et al. 2010, Arshad and Shah 2016, }\end{array}$ \\
\hline Tractor-powered forage harvester & $7.73^{\text {c }}$ & $0.77^{\text {c }}$ & - & $1.2^{\mathrm{a}-1.7}$ & Arvidsson and Lingvall 2005, Dalgaard et al. 2001 \\
\hline Self-propelled forage harvester & $7.96^{1 c}$ & $0.80^{\prime c}$ & $9.1-22$ & $\begin{array}{l}0.48-0.87 \\
\left(1.32-3.0^{(a)}\right)\end{array}$ & $\begin{array}{l}\text { Arvidsson and Lingvall 2005, Frost and Binnie } \\
\text { 2005, Grisso et al. 2010, Brownell et al. 2012, } \\
\text { Marsh } 2013\end{array}$ \\
\hline Self-loading forage wagon & 5.08 & 0.51 & $6.0-14^{(a}$ & $0.67-2.9^{\text {la }}$ & $\begin{array}{l}\text { Arvidsson and Lingvall 2005, Frost and Binnie } \\
\text { 2005, Brownell et al. } 2012\end{array}$ \\
\hline Combined baling and wrapping & 3.72 & 0.38 & $5.3-7.5$ & $1.6^{(\mathrm{b}}$ & $\begin{array}{l}\text { Dalgaard et al. 2001, Arvidsson and Lingvall 2005, } \\
\text { Grisso et al. 2010, Arshad and Shah 2016, }\end{array}$ \\
\hline $\begin{array}{l}\text { Transportation (forage harvester } \\
\text { methods) }\end{array}$ & - & $0.10^{\text {ld }}$ & $4.7^{1 c}$ & $0.2^{\text {(d }}$ & Arvidsson and Lingvall 2005, Dalgaard et al. 2001 \\
\hline Transportation of bales & - & $0.08^{(d)}$ & 1.6 & $0.16-0.4^{(e}$ & Arvidsson and Lingvall 2005, Dalgaard et al. 2001 \\
\hline $\begin{array}{l}\text { Filling and compressing silage } \\
\text { bunker }\end{array}$ & 3.5 & 0.35 & 1.5 & 0.5 & Arvidsson and Lingvall 2005, Dalgaard et al. 2001 \\
\hline
\end{tabular}

As Table 8 indicates, the reported range of fuel consumption in examined forage harvesting methods is wide. Combined with the unclear system definitions, the comparison of the results from this study with literature data is complicated. The sensitivity analysis of the created model indicated that variables such as working width have a significant effect on the fuel consumption of the examined methods, and it is often not reported in the literature. This is probably the main reason for the large variation in the reported fuel consumption values. Generally, it can be concluded that, most of the results from this study are within the range of variation found from the literature, or at least close to these margins. While many of the references also include transportation of the forage, this study considers only the field operations, and the energy consumption in transportations is analysed separately. This is likely to be the reason, why both modelled and measured fuel consumption figures in this study were close to, or below, the low end of the references in literature. One of the modelled results, which is clearly below the figures reported in literature, is the fuel consumption of the CBW method. Further confirmation is needed for re-defining the coefficients in the Equation 1 for this method.

\section{Conclusions}

According to the results from this study, it seems that no crucial differences between the fuel consumption of the examined methods existed, when the variables such as working width and yield level were equal. The measurements indicated the lowest energy consumption for the TPFH method. However, when the effect of working width was equalised by the model (e.g. Fig. 5), the most energy efficient method was SLFW method. The scaledup curve for CBW method would be somewhere between SLFW and TPFH \& SPFH methods in Figure 5 . With these prerequisites, the model could be generalised for approximate evaluation of fuel consumption in the examined forage harvesting methods.

Considering the transportation of forage from field to the storage facility, the TPFH, SPFH and CBW methods are more energy efficient than the SLFW method. When the transportation distance increases, this effect becomes emphasized. Therefore, it would be advisable to use some other forage harvesting method than SLFW when the transportation distances are long. 
Working width had a strong effect on the fuel consumption in the examined forage harvesting methods. It affects on the travelling distance in the field and engine load of the harvesting machinery. Since the width of single cutting unit of mower-conditioners is around four meters at maximum, it would always be advisable to combine the swaths from individual cutting units into a single windrow.

Although all the figures presented in this study are mainly approximate estimations, they are well suited for estimating the average fuel consumption in forage harvesting, apart from CBW method. Additionally, the data presented here offers information of the effect of several variables on the fuel consumption of forage harvesting operation. While the field operations and transportation of the forage are clearly separated from each other, the results enable calculation of fuel consumption for each farm and individual case. Further research could focus on scaling up the coefficients for the CBW method and additional field measurements and data acquisition for stronger validation of the model.

\section{Acknowledgements}

This study was funded by the Technical and Societal Research Foundation (Teknillis-yhteiskunnallinen tutkimussäätiö sr.). Authors present their gratitude to the financier.

\section{References}

Agri-Kymi Oy 2017. Specifications of Tempo PV 12 bale wagons. http://www.agrikymi.fi/fi/tyokoneet/peravaunut/paalivaunut. Accessed 13 April 2017. (in Finnish).

Arshad, I. \& Shah, A.R. 2016. Fuel consumption evaluation of different forage harvesting implements used for the harvesting of Rhodes grass. Science International (Lahore) 28: 4691-4696.

AGCO Finland Oy 2017a. Specifications of Valtra N-series tractors. http://www.valtra.fi/downloads/Valtra_N_sarja_Fl.pdf. Accessed 13 April 2017. (in Finnish).

AGCO Finland Oy 2017b. Specifications of Valtra A-series tractors. http://www.valtra.fi/downloads/Valtra_A_sarja_Fl.pdf. Accessed 13 April 2017. (in Finnish).

Ahokas, J. \& Jokiniemi, T. 2013. Traktorit. In: Ahokas, J. (ed.). Polttoaineen kulutus peltotöissä. Helsinki: University of Helsinki, Department of Agricultural Sciences. p. 8-23. (in Finnish).

Arvidsson, H. \& Lingvall, P. 2005. Harvesting silage with two types of silage trailer (feed rotor with knives and precision chop). In: Park, R.S. \& Stronge, M.D. (eds.). Silage production and utilisation. Proceedings of the XIVth International Silage Conference, in July in Belfast, North-Ireland, Wageningen: Wageningen Academic Publishers. p. 192-197.

ASABE 2011a. Agricultural Machinery Management. American Society of Agricultural and Biological Engineers, Standard EP 496.3. St Joseph: ASABE. p. 385-390.

ASABE 2011b. Agricultural Machinery Management Data. American Society of Agricultural and Biological Engineers, Standard D497.7. St Joseph: ASABE. 8 p.

B. Strautmann \& Söhne GmbH u. Co. KG 2017. Specifications of Strautmann Mega-Vitesse 3401 forage wagon. http://www.strautmann.de/english/Products/Forage\%20wagons/Mega-Vitesse\%20CFS.html. Accessed 13 April 2017.

Brownell, D.K., Liu, J., Hilton, J.W., Richard, T.L., Cauffman, G.R. \& Macafee, B.R. 2012. Evaluation of two forage harvesting systems for herbaceous biomass harvesting. Transactions of the ASABE 55: 1651-1658. https://doi.org/10.13031/2013.42348

Chianese, D.S., Rotz, C.A. \& Richard, T.L. 2009. Whole-farm greenhouse gas emissions: a review with application to a Pennsylvania dairy farm. Applied Engineering in Agriculture 25: 431-442. https://doi.org/10.13031/2013.26895

Culpin, C. 1986. Farm Machinery. 11th ed. London: William Collins Sons \& Co. Ltd. 450 p.

Dalgaard, T., Halberg, N. \& Porter, J.R. 2001. A model for fossil energy use in Danish agriculture used to compare organic and conventional farming. Agriculture, Ecosystems and Environment 87: 51-65. https://doi.org/10.1016/S0167-8809(00)00297-8

Deere \& Company 2017. Specifications of John Deere 7180 self-propelled forage harvester. http://viewer.zmags.com/publication/17ed8328. Accessed 13 April 2017.

Esala, J. 2013. Nurmikasvien viljely. In: Ahokas, J. (ed.). Polttoaineen kulutus peltotöissä. Helsinki: University of Helsinki, Department of Agricultural Sciences. p. 70-84.

European Union 2012. Directive 2012/27/EU of the European parliament and of the council of 25 October 2012 on energy efficiency, amending Directives 2009/125/EC and 2010/30/EU and repealing Directives 2004/8/EC and 2006/32/EC. Official Journal of the European Union. http://eur-lex.europa.eu/LexUriServ/LexUriServ.do?uri=OJ:L:2012:315:0001:0056:en:PDF. Accessed 13 April 2017.

Frost, J.P. \& Binnie, R.C. 2005. The effect of silage harvester type on harvesting efficiency. In: Park, R.S. \& Stronge, M.D. (eds.). Silage production and utilisation. Proceedings of the XIVth International Silage Conference, in July in Belfast, North-Ireland. Wageningen: Wageningen Academic Publishers. p. 191.

Grisso, R.D., Perumpral, J.V., Vaughan, D.H., Roberson, G.T. \& Pitman, R. 2010. Predicting tractor diesel fuel consumption. Virginia Cooperative Extension publication 443-073. $10 \mathrm{p}$. 
Hankkija Oy 2017. Specification of Krone KS 900 Plus rotary rake. https://www.hankkija.fi/Koneet/nurmenviljely/poyhimet-jakarhottimet/krone-ks900-plus-karhotin/. Accessed 13 April 2017. (in Finnish).

Jokiniemi, T., Suokannas, A. \& Ahokas, J. 2016. Energy consumption in agriculture transportation operations. Engineering in Agriculture, Environment and Food 9: 171-178. https://doi.org/10.1016/j.eaef.2015.11.001

Junkkari Oy 2017. Specifications of Junkkari J16JL agricultural wagon. http://www.junkkari.fi/junkkari-j-16. Accessed 13 April 2017. (in Finnish).

K-maatalous 2015. Specifications of JF FCT 960 forage harvester. https://www.k-maatalous.fi/globalassets/product-integration/ liitteet/jf_fct_960-1460_esite_2015_b.pdf. Accessed 13 April 2017. (in Finnish).

Kristensen, T., Mogensen, L., Trydeman Knudsen, M. \& Hermansen, J.E. 2011. Effect of production system and farming strategy on greenhouse gas emissions from commercial dairy farms in a life cycle approach. Livestock Science 140: 136-148. https://doi.org/10.1016/j.livsci.2011.03.002

Küper, J.-M. \& Höner, G. 2010. Kleine Rotoren: Besserer Schnitt bei gleichen PS. Top Agrar 3: 128-131.

KTBL 2017. Dieselbedarfsrechner. Kuratorium für Technik und Bauwesen in der Landwirtschaft. http://daten.ktbl.de/dieselconsumption/home.html. Accessed 13 April 2017.

Marsh, B.H. 2013. A Comparison of Fuel Usage and Harvest Capacity in Self-Propelled Forage Harvesters. International Journal of Biological, Biomolecular, Agricultural, Food and Biotechnological Engineering 7: 649-654.

Mikkola, H. \& Ahokas, J. 2009. Energy ratios in Finnish agricultural production. Agricultural and food science 18: 332-346. https://doi.org/10.23986/afsci.5958

Motiva 2015. Maatilojen energiaohjelma. http://www.energiatehokkuussopimukset.fi/fi/sopimusalat/maatilat/. Accessed 13 April 2017. (in Finnish).

Myyrä, S. 2002. Tilusrakenteen vaikutus tuotannon järjestämiseen ja kannattavuuteen. MTT Taloustutkimus, tutkimuksia 253. Vammalan Kirjapaino Oy. 35 p. (in Finnish).

NHK-keskus 2017. Specifications of Welger RPC 245 baler-wrapper. http://www.nhk.fi/tks/19/yhdistelmapaalaimet.html. Accessed 13 April 2017. (in Finnish).

Niskanen, H. 1985. Traktorit, työkoneet ja maatalouskoneet. Helsinki: Kustannusosakeyhtiö Tammi. 641 p. (in Finnish).

Oy Elho Ab 2017. Specifications of Elho Arrow 3700 mower conditioner. http://www.elho.fi/tuotteet/niittomurskaimet-ja-niittokoneet/elho-arrow-3700-elho-arrow-3700-sideflow. Accessed 13 April 2017. (in Finnish).

Renius, K.T. 1999. Tractors: Two Axle Tractors. In: Stout, B.A. \& Cheze, B. (eds.). CIGR Handbook of Agricultural Engineering, Volume III: Plant Production Engineering. St Joseph: ASAE. p. 115-184.

Rinaldi, M., Erzinger, S. \& Stark, R. 2005. Treibstoffverbrauch und Emissionen von Traktoren bei landwirtschaftlichen Arbeiten. FAT-Schriftenreiche Nr. 65. 92 p.

Robert Bosch GmbH 2004. Bosch Automotive handbook. 6th ed. Germany: Wiley-Blackwell. 1234 p.

Shortall, O.K. \& Barnes, A.P. 2013. Greenhouse gas emissions and the technical efficiency of dairy farmers. Ecological Indicators 29: 478-488. https://doi.org/10.1016/j.ecolind.2013.01.022

Srivastava, A.K., Goering, C.E., Rohrbach, R.P. \& Buckmaster, D.R. 2006. Engineering Principles of Agricultural Machines. 2nd ed. St Joseph: ASABE. 569 p.

Suokannas, A. 2003. Esikuivatun säilörehun korjuuketjut. In: Kallioniemi, M. (ed.). Maatalouden uusi teknologia - tarkkuutta ja tehokkuutta. Vihti: MTT Agrifood Research Finland. p. 60-66. (in Finnish).

Tremblay, D., Savoie, P. \& LePhat, Q. 1997. Power requirements and bale characteristics for a fixed and variable chamber baler Canadian agricultural engineering 39: 73-76.

Udompetaikul, V., Upadhyaya, S.K. \& Vannucci, B. 2011. The effect of tire inflation pressure on fuel consumption of an agricultural tractor operating on paved roads. Transactions of the ASABE 54: 25-30. https://doi.org/10.13031/2013.36249

Vallinhovi, S., Anttila, A., Niskanen, M., Palva, R. \& Puumala, L. 2014. NurmiArtturi. Hävikit kuriin ja säilörehun laadunvaihtelu hallintaan. Vaasa: NurmiArtturi-hanke. 24 p. (in Finnish).

Van linden, V. \& Herman, L. 2014. A fuel consumption model for off-road use of mobile machinery in agriculture. Energy 77: 880889. https://doi.org/10.1016/j.energy.2014.09.074 